\title{
Peran Job Insecurity terhadap Stres Kerja dengan Moderator Religiusitas
}

\author{
Muhammad Farid Bashori ${ }^{1} \mathcal{E}$ IJK Sito Meiyanto ${ }^{2}$ \\ Fakultas Psikologi Universitas Gadjah Mada
}

\begin{abstract}
Stress is one of the psychological reactions that can be in a work situation. Work situations may change at any time in different forms. An employee's psychological reaction to change also varies. Job insecurity arising from changing work situations increases job stress. A company certainly does not want employees to experience work stress that can impact on the decline in company performance. The level of employee religiosity is expected to reduce the impact of job insecurity. This study aims to determine the role of job insecurity against work stress moderated by religiosity. Job stress as dependent variable, job insecurity as independent variable, and religiosity as moderator. Methods of data retrieval were performed using work stress scale, job insecurity scale, and scale of religiosity. The subjects of this study were 119 employees working in the State Forestry Corporation. The hypothesis proposed in this study is religiosity as a moderator in the relationship between job insecurity with work stress. Moderate and hypothesis test is done by moderate regression analysis. The research result shows religiosity not proved as moderator in relationship between job insecurity with work stress, but directly significant impact to work.
\end{abstract}

Keywords: job insecurity; religiosity; work stress

Abstrak. Stres merupakan salah satu reaksi psikologis yang dapat dialami dalam situasi kerja. Situasi kerja dapat berubah setiap saat dalam bentuk yang berbeda-beda. Reaksi psikologis seorang karyawan menyikapi suatu perubahan juga berbeda-beda. Job insecurity yang timbul dari perubahan situasi kerja berpotensi meningkatkan stress kerja. Sebuah perusahaan tentunya tidak menginginkan karyawan mengalami stres kerja yang dapat berdampak pada penurunan kinerja perusahaan. Tingkat religiusitas karyawan diharapkan dapat menurunkan dampak dari job insecurity. Penelitian ini bertujuan untuk mengetahui peran job insecurity terhadap stress kerja yang dimoderasi oleh religiusitas. Stress kerja sebagai variabel tergantung, job insecurity sebagai variabel bebas, dan religiusitas sebagai moderator. Metode pengambilan data dilakukan melalui survei dengan menggunakan skala stres kerja, skala job insecurity, dan skala religiusitas. Subjek penelitian ini adalah 119 karyawan yang bekerja di sebuah BUMN sektor kehutanan. Hipotesis yang diajukan dalam penelitian ini adalah religiusitas berperan sebagai moderator dalam hubungan antara job insecurity dengan stres kerja. Uji moderator dan hipotesis dilakukan melalui moderated regression analysis. Hasil penelitian menunjukkan religiusitas tidak terbukti berperan sebagai moderator dalam hubungan antara job insecurity dengan stres kerja, namun berperan langsung secara signifikan terhadap stres kerja.

Kata kunci: job insecurity, religiusitas, stres kerja

\footnotetext{
${ }^{1}$ Korespondensi mengenai isi artikel ini dapat di-lakukan melalui muhammad.farid.b@mail.ugm.ac.id

2 Atau melalui smeiyanto@ugm.ac.id 
Stress menurut Lazarus \& Folkman (1984) merupakan hasil interaksi antara pribadi orang tersebut dengan lingkungannya di mana ia menilai interaksi tersebut membahyakan dirinya dan melebihi kemampuannya untuk mengatasi. Stres yang terjadi meliputi rasa takut, kemungkinan kehilangan, dan kecemasan terhadap masa depan pekerjaan. Gejala lain yang ditemukan yaitu susah tidur, pusing dan kehilangan nafsu makan.

International Labour Organization (ILO) (dalam Sur \& $\mathrm{Ng}$, 2014) mendefinisikan stres kerja dalam ensiklopedianya sebagai respon dari interaksi antara pekerjaan dan seorang karyawan. Pekerjaan yang dimaksud adalah beban kerja yang harus dikerjakan seorang karyawan, sedangkan karyawan yang dimaksud adalah atribut yang berkaitan dengan kebutuhan, harapan dan kapasitas sumber daya yang dimiliki (Sauter, Hurrel, Murphy, Levi, 1997). National Institute for Occupational Safety and Health (NIOSH) mendefinisikan stress sebagai interaksi antara karakteristik pekerja dengan kondisi kerja tertentu. Penekanan NIOSH terletak pada kondisi kerja tertentu dengan asumsi bahwa respon karyawan terhadap kondisi kerja yang sama belum tentu berdampak stress kerja, jadi hanya kondisi kerja yang spesifik yang memengaruhi seorang karyawan secara individual. Robbins dan Judge (2015) mendefinisikan stres sebagai suatu kondisi dinamis yaitu individu berkonfrontasi dengan tuntutan, dan sumber daya yang terkait dengan harapan individu dan kemungkinan dampak yang akan terjadi.

Penelitian mengenai stres sampai dengan tahun 1980-an memusatkan perhatian pada dampak fisik dan kesehatan mental (Baba, Jamal, dan Tourigny, 1998; Danna dan Griffin, 1999) daripada faktor penentu atau bagaimana proses terbentuknya stres. Tahun 1980-an mulai banyak penelitian stres kerja yang membahas dari sisi organisasi. Jamal (1984) melihat stres kerja dari sudut pandang reaksi seorang karyawan terhadap karakteristik lingkungan kerja. Penelitian mengenai stres dalam perkembangannya diperluas dengan memasukkan unsur demografis seperti gender, usia dan etnis. Sumber stres dilihat secara situasional seperti demand role ambiguity, job control, time pressure. Karasek (dalam Sur dan Ng, 2014) adalah peneliti awal yang mengemukakan job control sebagai cara untuk menurunkan stres kerja. Ganster dan Rosen (2013) mengemukakan job control berfungsi menghambat laju stres kerja yang disebabkan oleh beban kerja, konflik, dan lain-lain. Job control yang rendah dan reward yang tidak seimbang meningkatkan stres kerja (Tsutsumi, Kayaba, Theorel, Siegrist, 2001). Tsutsumi et al, selanjutnya menyatakan ancaman kehilangan pekerjaan meningkatkan depresi terutama pada karyawan yang terlibat langsung dengan pekerjaan, dan berpengaruh juga pada supporting staff.

Robbins dan Judge menyatakan seseorang yang mengalami stress dapat dilihat melalui tanda-tanda berupa gejala fisiologis, gejala psikis, dan gejala perilaku. Pendapat ini didukung oleh penelitian yang dilakukan Ganster dan Rosen (2013) yang mengemukakan stres kerja ditandai dengan meningkatnya rasa cemas, ketegangan dan secara fisiologis dapat meningkatkan tekanan darah, kolesterol, penyakit jantung. Penelitian lain yang dilakukan oleh Jamal (1984) mengemukakan bahwa stress kerja dapat memunculkan perilaku menarik diri dalam bentuk ketidakhadiran kerja, kelambanan dalam bekerja, dan turnover. 
Potensi stres kerja dapat dialami oleh karyawan dari berbagai sektor. Karyawan perum perhutani yang bergerak di sektor kehutanan tidak terlepas dari ancaman potensi stress kerja. Terlebih dengan wilayah kerja sekitar 2,4 juta hektar dengan jumlah karyawan 24 ribu orang mengemban tugas berat untuk mengamankan hutan, asumsinya setiap karyawan mengamankan 100 hektar. Penelitian yang dilakukan oleh Mc Elwee (2008) menunjukkan bahwa kerusakan hutan dapat disebabkan oleh faktor ekonomi yaitu keinginan manusia untuk memenuhi kebutuhan hidup. Krisis ekonomi yang pernah dialami Indonesia berdampak pada menurunnya kemampuan masyarakat untuk memenuhi kebutuhan hidup. Bagi masyarakat sekitar hutan krisis ekonomi meningkatkan ketergantungannya pada hasil hutan. Ketergantungan masyarakat sekitar hutan yang dapat mengancam kelestarian hutan berwujud pengambilan hasil hutan secara langsung dengan menebang pohon, perambahan hutan untuk bercocok tanam, penggembalaan ternak, klaim kepemilikan tanah pada wilayah hutan negara.

Peluso (2011) dalam penelitiannya menyatakan adanya ketergantungan masyarakat desa hutan kepada hutan negara di jawa. Di jawa ada sekitar 6000 desa yang seperempatnya berada di wilayah sekitar hutan dan mempunyai ketergantungan kepada hutan. Ada beberapa kelompok yang melakukan penebangan liar, beberapa kelompok diantaranya terorganisir. Pada tahun 1998 sampai dengan 2008 data yang tercatat sebanyak 99 orang ditembak oleh polisi hutan, 31 diantaranya ditembak mati. Hasil wawancara menunjukkan gejala stres kerja berupa kecemasan, rasa takut dan gangguan kesehatan pada personil yang mengalami kejadian dan berhadapan langsung dengan gejolak massa/amuk massa sebagai efek penegakan hukum yang dilakukan di beberapa wilayah satuan kerja.

Perambahan hutan menyebabkan persediaan kayu perhutani menurun tajam dengan kehilangan lebih dari $40 \%$ sebanyak 16,1 juta meter kubik. Dengan rata-rata kehilangan kayu pertahun sebanyak 2,7 juta meter kubik. Berdasarkan laporan tahunan resmi yang dipublikasikan Pendapatan perhutani pada tahun 2015 menurun dari 4,6 trilyun menjadi 4,1 trilyun dari tahun sebelumnya, berdampak pada laba bersih perusahan turun dari 264 milyar menjadi 166 milyar. Pendapatan tahun 2016 diperkirakan mengalami penurunan yang signifikan dengan beberapa kali dilakukan penyesuaian Cost Reduction Program (CRP).

Beberapa kebijakan yang diambil yaitu restrukturisasi, penetapan target tinggi hasil hutan non kayu, dan meminimalkan gangguan keamanan hutan. Kebijakan restrukturisasi organisasi di awal tahun 2017 dilakukan, namun beberapa karyawan menyayangkan mutasi untuk mengisi jabatan hasil restrukturisasi dilakukan sebelum proses asesmen karyawan selesai seluruhnya, respon lain yang muncul adalah ketidakhadiran karyawan. Kebijakan target tinggi pada hasil hutan non kayu sebagai contoh di salah satu Kesatuan Pemangkuan Hutan dibebani target 10.000 ton getah pinus dari kapasitas maksimal produksi getah pohon pinus 8.000 ton. Gangguan keamanan hutan dalam bentuk penebangan pohon tanpa ijin maupun kebakaran hutan karena faktor alam menuntut karyawan untuk selalu siaga. Beban kerja yang di alami karyawan berpotensi menimbulkan stres kerja. Kondisi yang serupa dinyatakan oleh salah satu ajun wilayah Kesatuan 
Pemangkuan Hutan bahwa tuntutan pekerjaan membuat anak buahnya kadangkala mengalami pusing kepala. Ajun wilayah yang lain menyatakan ketika ia memberikan informasi target yang harus dicapai kepada anak buahnya maka reaksi yang muncul adalah keluhan karena tingginya target melebihi potensi sumberdaya alam. Ajun wilayah tersebut juga menyatakan anak buahnya menjadi lebih sensitif secara emosional. Stress kerja karyawan perlu diperhatikan perusahaan karena sesuai dengan penelitian yang dilakukan oleh Erat, Kitapci, dan Comez (2017) menyatakan adanya hubungan antara beban kerja dengan stress kerja berupa gejala fisik dan psikologis

$$
\text { Robbins dan Judge }
$$

berpendapat bahwa penyebab stres kerja secara umum dapat digolongkan menjadi tiga yaitu: faktor lingkungan, faktor organisasional, dan faktor pribadi. Lingkungan kerja yang tidak pasti selain akan memengaruhi desain dari struktur organisasi juga memengaruhi level stres di antara karyawan dalam organisasi tersebut. Perubahan lingkungan organisasi dapat dipengaruhi perubahan ekonomi, politik, dan teknologi. Ketika ada perubahan yang cukup besar pada lingkup ekonomi, politik, dan teknologi, maka sebuah organisasi harus bersiap menghadapi perubahan lingkungan tersebut. Faktor organisasional adalah stressor yang berasal dari dinamika di dalam organisasi. Dinamika organisasi banyak kemungkinan memunculkan stressor, seperti tekanan untuk menghindari kesalahan atau menyelesaikan tugas dalam waktu yang terbatas, beban kerja yang berlebihan, atasan yang sangat menuntut, rekan kerja yang tidak menyenangkan. Faktor di dalam kehidupan pribadi seseorang karyawan meliputi: permasalahan keluarga, permasalahan ekonomi pribadi dan karakteristik kepribadian karyawan. Seorang karyawan yang mengalami gejala stress kerja sebelum memulai pekerjaan akan mengalami stress kerja beberapa bulan kemudian.

Organisasi bisnis mengalami siklus pasang dan surut. Ketika organisasi mengalami kondisi krisis, maka organisasi tersebut biasanya akan melakukan perubahan. Perubahan akan dilakukan oleh organisasi tersebut dalam skala besar ataupun kecil. Seorang karyawan yang mempersepsikan seberapa besar adanya perubahan yang terjadi pada organisasi maka job insecurity akan naik atau turun mengikuti besarnya perubahan organisasi tersebut (Ashford, et al., 1989)

Penjelasan sebelumnya menyatakan bahwa salah satu faktor penyebab stress kerja adalah faktor lingkungan. Perubahan lingkungan kerja perum perhutani dapat menimbulkan ketidakpastian bagi karyawan bahkan ancaman kehilangan pekerjaan atau jabatan ketika perusahaan mengalami permasalahan keuangan dalam jangka panjang. Penelitian yang dilakukan oleh Park, Rhee, dan Barak (2016) menyatakan para karyawan yang mengalami gangguan mental yang diasosiasikan dengan stress kerja disebabkan oleh job insecurity dan rendahnya penghasilan. Penelitian tersebut menunjukkan job insecurity sebagai salah satu penyebab stress kerja. Ada beberapa ahli yang mendefinisikan job insecurity. Ashford, et al., (1989) menyatakan job insecurity sebagai kondisi mental seorang karyawan di mana karyawan merasa pekerjaannya terancam dan karyawan tidak berdaya untuk melakukan sesuatu untuk mengatasi masalah tersebut. Berdasar definisi tersebut ada dua aspek yang membentuk job insecurity yaitu perasaan terancam 
terhadap pekerjaannya dan perasaan tidak berdaya untuk mengatasi situasi. Perasaan terancam pekerjaannya dapat berupa kehilangan pekerjaan dalam arti pemutusan hubungan kerja atau kehilangan jabatan yang saat ini didapatkannya. Sedangkan perasaaan tidak berdaya terhadap situasi adalah ketidakmampuan mengatasi situasi perubahan pekerjaan di masa yang akan datang. Tidak adanya kontrol terhadap situasi pekerjaan meningkatkan job insecurity. Penelitian yang dilakukan Ganster dan Rosen (2013) memperkuat pendapat bahwa job control berfungsi menghambat laju stres kerja. Ancaman kehilangan pekerjaan atau jabatan sebagai salah satu aspek job insecurity dapat memengaruhi stres kerja diperkuat oleh penelitian yang dilakukan Tsutsumi, et al., (2001), bahwa ancaman kehilangan pekerjaan meningkatkan depresi.

Greenhalg dan Rosenblatt (1984) menyatakan bahwa job insecurity adalah ketidakberdayaan untuk mempertahankan kesinambungan yang diinginkan dalam situasi pekerjaan yang terancam. Penelitian sebelumnya dikritik karena dianggap gagal membangun konsep dan tidak memperjelas konsep teoritis. Mereka mecoba merumuskan konsep yang lebih jelas mengenai job insecurity yaitu konstruk yang multidimensi. Job insecurity adalah persepsi terhadap ancaman terhadap masa depan pekerjaan seperti kesempatan untuk promosi atau kebebasan untuk mengatur waktu kerjanya sendiri, semakin besar seorang mempersepsikan ancaman terhadap pekerjaannya di masa depan maka semakin besar pula job insecurity. Penelitian oleh Greenhalgh dan Rosenblatt (1984) menunjukkan adanya hubungan antara job insecurity dengan stres, yang selanjutnya menyatakan bahwa job insecurity merupakan sumber stres.
Ada bermacam cara orang beradaptasi terhadap stress, salah satu yang dilakukan melalui pendekatan religiusitas. Penelitian yang dilakukan oleh Roostaee, Nikmanesh, Sharifi-Rad, Kiani, \& Shahnazi (2016) menyatakan adanya hubungan negatif antara religious coping dengan stress kerja. Semakin tinggi tingkat religiusitas seseorang dalam menghadapi masalah maka akan semakin rendah tingkat stres dalam menghadapi masalah kerja. Faktor terbesar yang berhubungan dengan stres kerja adalah aktivitas religius. Aktivitas religius dapat dijelaskan sebagai seberapa sering seseorang mengikuti kegiatan yang berhubungan dengan keagamaan. Apabila dihubungkan dengan konteks keagamaan di Indonesia maka aktivitas keagamaan dapat berwujud pengamalan ritual keagamaan rutin seperti ibadah atau aktivitas lain yang dapat menambah tingkat keimanan seseorang misalnya pengajian atau memperdalam ilmu pengetahuan agama.

Pengertian religion menurut Glock dan Stark seperti yang dikutip oleh Ancok dan Suroso (2011) adalah sistem simbol, keyakinan, nilai dan perilaku yang dihayati dan dimaknai. Glock dan Stark mengemukakan dimensi religiusitas ada 5 yaitu: Keyakinan, Ritual, Pengalaman, Pengetahuan Agama, dan Konsekuensi. Dimensi keyakinan berisi pengharapan dalam bentuk keyakinan akan kebenaran terhadap doktrin-doktrin agama. Dimensi ritual berkaitan dengan praktik peribadatan untuk menunjukkan komitmen terhadap agama. Dimensi pengalaman berkaitan dengan perasaan atau sensasi kedekatan dengan Tuhannya. Pengetahuan agama berkaitan dengan pengetahuan dasar pemeluk agama terhadap ajaran agama. Dimensi 
konsekuensi berkaitan dengan identifikasi akibat-akibat keyakinan keagamaan.

Idler, Musick, Ellison, George, Krause, dan Ory (2003) melakukan penelitian mengenai dimensi religiusitas dan kesehatan dengan menggunakan dimensi religiusitas yaitu: personal religious/spiritual history, public religious practice, dan private religious practice. Personal religious practice merupakan pengalaman keberagamaan seseorang. Koenig, George, Blazer, Meador, dan Dyk (1994) melaporkan penelitiannya mengenai pengalaman keberagamaan hidup seseorang berdampak lebih sedikit mengalami gangguan depresi, pada penelitian lain, Koenig, Ford, George, Blazer, dan Meador (1993) menyatakan seseorang yang mempunyai pengalaman keberagamaan akan lebih sedikit mengalami gangguan kecemasan. Dimensi yang kedua yaitu public religious practice yaitu sejauh mana seseorang melakukan aktivitas keberagaman pada pusat peribadatan. Dimensi ketiga yaitu private religious practice yaitu sejauh mana nilainilai keberagamaan dinternalisasikan dalam kehidupannya.

Pendapat Fetzer (1999) mengenai religiusitas yaitu suatu hal yang berkaitan dengan perilaku, social, dan doktrin dari setiap agama dan wajib diikuti oleh pemeluknya. Pendapat senada dikemukakan Boswell dan Boswell (2010) yang menyatakan religiusitas adalah kepatuhan terhadap dogma agama dan kepercayaan, ekspresi keyakinan moral dalam wujud peribadatan secara bersamasama atau mandiri. Menurut penelitian Ismirani (2011) menunjukkan bahwa religiusitas mempunyai pengaruh yang signifikas terhadap stres kerja. Stres kerja yang tidak tertangani dapat berubah menjadi depresi.
Stres kerja yang cukup menurut Handoko (2013) mampu meningkatkan prestasi kerja namun apabila stress kerja terlalu besar maka akan menghasilkan prestasi kerja yang sangat rendah. Suatu organisasi perlu memperhatikan stres kerja karyawannya untuk mendapatkan hasil kerja optimal. Penelitian yang dilakukan oleh Astianto (2014) menunjukkan hubungan terbalik. Seorang karyawan yang mengalami kenaikan stress kerja sebesar 1 satuan, maka dapat menurunkan kinerja karyawan sebesar 0,16 . Astianto selanjutnya menambahkan stres kerja yang cukup dapat mendorong karyawan memberikan tanggapan terhadap tantangan-tantangan pekerjaan. Stres kerja yang cukup dengan tingkat intensitas pembebanan yang optimum, dalam arti tidak terlalu besar atau terlalu kecil dapat memacu prestasi kerja karyawan.

Organisasi tentunya tidak menginginkan penurunan kinerja perusahaan. Jamal (2011) menyatakan adanya hubungan linear terbalik antara stres kerja dan kinerja karyawan. Berdasarkan beberapa penelitian di atas maka penting bagi organisasi untuk memperhatikan tingkat stres kerja karyawannya. Terlalu sedikitnya stimulus atau tantangan pekerjaan atau tidak adanya stres kerja maka karyawan tidak akan terpacu menampilkan kinerja terbaik mereka, namun apabila tingkat stress kerja terlalu tinggi maka akan berpotensi menimbulkan burnout atau bahkan depresi.

Mengacu pada konsep yang dikemukakan Robbins dan Judge (2015) stres dihubungkan dengan tuntutan dan sumber daya. Tuntutan merupakan tanggung jawab, tekanan, kewajiban, dan ketidakpastian yang dihadapi oleh para individu di tempat kerja. Sumber daya 
merupakan hal-hal di dalam kendali individu yang dapat ia pergunakan untuk menyelesaikan tuntutan. Mengacu pada antara job insecurity dengan stress kerja. Sedangkan penelitian ini bertujuan untuk menguji peran religiusitas yang

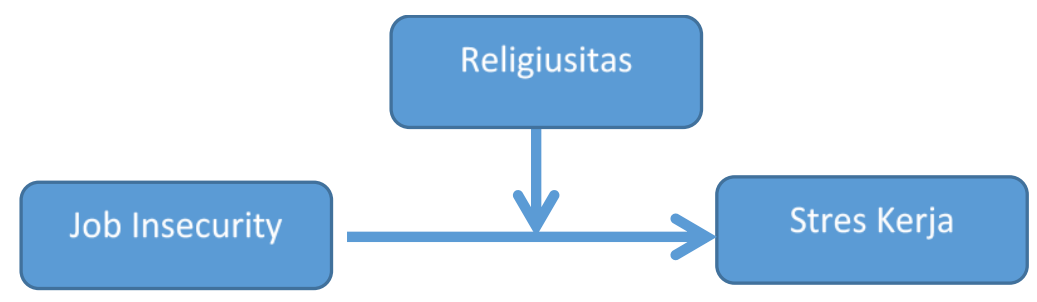

Gambar 1. Kerangka Konseptual Penelitian

konsep di atas job insecurity berkaitan dengan tuntutan di lingkungan pekerjaan sedangkan religiusitas dapat dipergunakan sebagai sumber daya yang dapat dikelola oleh seorang karyawan.

Penelitian ini menggunakan tiga variabel yaitu variabel tergantung, bebas dan moderator. Stress kerja sebagai variabel tergantung, job insecurity sebagai variabel bebas, sedangkan religiusitas sebagai variabel moderator. Variabel moderator menurut Urbayatun dan Widhiharso (2012) menjadi penentu kuat lemahnya peranan variabel bebas terhadap variabel tergantung. Mekanisme hubungan antar variabel dalam penelitian ini adalah peranan job insecurity terhadap stress kerja tergantung dari religiusitas individu. Jika individu memiliki religiusitas yang tinggi maka job insecurity tersebut peranannya akan berkurang. Safaria (2011) mengemukakan religious dapat berperan sebagai moderator dari job insecurity terhadap stress kerja.

Berdasarkan latar belakang yang telah dijelaskan, peneliti tertarik untuk meneliti seberapa besar religiusitas berperan sebagai moderator hubungan antara job insecurity dengan stres kerja pada karyawan perum perhutani.

Hipotesis yang dibangun dalam penelitian ini adalah religiusitas berperan sebagai moderator dalam hubungan memoderasi hubungan antara job insecurity dengan stres kerja. Penelitian ini diharapkan mampu memberikan kontribusi kepada akademisi dan praktisi di bidang Psikologi Industri dan Organisasi mengenai pengembangan faktor-faktor yang mampu menurunkan tingkat stress kerja pada karyawan. Selain itu, penelitian ini diharapkan juga dapat menjadi acuan untuk penelitian selanjutnya yang berkaitan dengan job insecurity, stress kerja, dan religiusitas. Implikasi praktis penelitian ini diharapkan memberikan gambaran mengenai tingkat stress kerja, tingkat job insecurity dan tingkat religiusitas pada karyawan perum perhutani.

\section{Metode}

Penelitian ini akan diuji dengan menggunakan metode kuantitatif melalui survei. Pendekatan kuantitatif menurut Creswell (2012) mempunyai karakteristik mendeskripsikan permasalahan penelitian melalui hubungan antar variabel dengan menetapkan tujuan penelitian, hipotesis dengan menghimpun data numerik dengan menggunakan instrumen, kemudian dilakukan analisis dan melaporkan hasil penelitian. Survei merupakan prosedur di penelitian kuantitatif dimana peneliti mengambil sampel dari suatu populasi untuk 
mendapatkan data kuantitatif melalui kuesioner atau wawancara sebagai bahan untuk analisis statistik untuk pengujian hipotesis.

Teknik pengambilan sampel yang akan digunakan dalam penelitian ini adalah teknik purposive sampling. Purposive sampling adalah pemilihan sekelompok subjek didasarkan ciri atau sifat tertentu yang telah ditentukan sebelumnya.
Sebelum analisis data, peneliti melakukan pengukuran reliabilitas skala dengan menggunakan data uji coba. Hasil uji coba reliabilitas skala dapat dilihat pada Tabel 1.

Data komposisi demografi subjek dalam penelitian ini dijabarkan dalam Tabel 2.

Tabel 1.

Hasil Uji Coba Reliabilitas Skala Penelitian

\begin{tabular}{|c|c|c|c|c|c|}
\hline \multirow[b]{2}{*}{ Skala } & \multicolumn{2}{|c|}{$\sum$ aitem } & \multirow{2}{*}{$\begin{array}{c}\text { Aitem } \\
\text { dianulir }\end{array}$} & \multicolumn{2}{|r|}{$\alpha$} \\
\hline & $\begin{array}{l}\text { Sebelum uji } \\
\text { coba }\end{array}$ & $\begin{array}{l}\text { Setelah Uji } \\
\text { Coba }\end{array}$ & & $\begin{array}{l}\text { Seluruh } \\
\text { aitem }\end{array}$ & $\begin{array}{c}\text { Tanpa aitem yang } \\
\text { dianulir }\end{array}$ \\
\hline Stres Kerja & 27 & 22 & $6,8,9,13,24$ & 0,892 & 0,906 \\
\hline Job Insecurity & 17 & 15 & 8,10 & 0,860 & 0,883 \\
\hline Religiusitas & 40 & 37 & $2,29,40$ & 0,939 & 0,942 \\
\hline
\end{tabular}

Tabel 2.

Komposisi Demografi Subjek

\begin{tabular}{llcc}
\hline Demografi & Data & Jumlah & Persentase \\
\hline Jenis Kelamin & Laki-laki & 119 & $100 \%$ \\
& Perempuan & 0 & $0 \%$ \\
\hline Usia & $<40$ tahun & 35 & $29,4 \%$ \\
& $40-50$ tahun & 73 & $61,3 \%$ \\
& $>50$ tahun & 11 & $9,2 \%$ \\
\hline \multirow{2}{*}{ Masa Kerja } & $2-15$ tahun & 18 & $15,1 \%$ \\
& $16-25$ tahun & 90 & $75,6 \%$ \\
& $>25$ tahun & 11 & $9,2 \%$ \\
\hline
\end{tabular}

Pengumpulan data dilakukan dengan menggunakan skala psikologi sebagai alat ukur variabel yang diuji dalam penelitian ini.

\section{Hasil}

Penelitian ini terdiri dari 164 data subjek, 45 diantaranya diolah sebagai data uji coba alat ukur. Sisanya sebanyak 119 data subjek dijadikan sebagai data analisis penelitian. hipotesis dilakukan uji regresi berganda. Analisis moderator dilakukan dengan metode yang dikemukakan Baron dan Kenny (1986) dengan memperhatikan kondisi-kondisi yang harus terpenuhi, yaitu: (1) setiap variabel independen menunjukkan hubungan yang signifikan dengan variabel dependen untuk memastikan bahwa ada efek menyeluruh dari moderasi; (2) variabel independen dengan variabel moderator memiliki kedudukan yang setara; (3) variabel moderator merupakan variabel yang bisa 
memberikan peran memperlemah atau memperkuat pengaruh variabel independen terhadap variabel dependen; (4) variabel moderator merupakan variabel yang dapat memoderasi berdasarkan hasil pengujian. religiusitas berperan sebagai moderator dalam hubungan antara job insecurity dengan stres kerja tidak terbukti.

Peneliti kemudian mencoba melihat peranan langsung religiusitas terhadap stress kerja secara langsung. Hasilnya

Tabel 4.

Uji Moderator

\begin{tabular}{|c|c|c|c|c|}
\hline \multirow{2}{*}{ Predictor } & \multicolumn{2}{|c|}{ Stres Kerja } & \multirow[b]{2}{*}{$\mathrm{B}$} & \multirow[b]{2}{*}{$\mathrm{p}$} \\
\hline & $\mathrm{R}$ & R Square & & \\
\hline $\begin{array}{l}\text { Step } 1 \\
\quad \text { Job Insecurity }\end{array}$ & .478 & .229 & .478 & .000 \\
\hline Step 2 & .543 & .295 & & \\
\hline Job Insecurity & & & .400 & .000 \\
\hline Religiusitas & & & -.269 & .001 \\
\hline Step 3 & .544 & .295 & & \\
\hline Job Insecurity & & & .136 & .892 \\
\hline Religiusitas & & & -.894 & .373 \\
\hline Job Insecurity $x$ Religiusitas & & & .335 & .738 \\
\hline
\end{tabular}

Hasil regresi variabel penelitian tampak pada tabel 3 .

Berdasarkan Tabel 3. dapat dijelaskan tahapan regresi yang dilakukan. Pada tahap pertama job insecurity diregresikan ke dalam stress kerja. Hasilnya menunjukkan job insecurity memiliki peran yang signifikan dalam memprediksi stress kerja $\quad(B=.0,478, \mathrm{p}=0,00 ; \mathrm{p}<0,01) \quad$ dengan sumbangan predictor sebesar $22,9 \%$. Tahap kedua dengan memasukkan variabel religiusitas ke dalam perhitungan. Didapatkan peningkatan sumbangan efektif sebesar 5,63\%, dari 22,9\%, menjadi $29,5 \%$ dengan peran masing-masing variabel masih signifikan, variabel job insecurity $\mathrm{B}=.400 \mathrm{p}=0.000(\mathrm{p}<0,01)$, variabel religiusitas $B=-.269 p=.001(p<0,01)$ Tahap ketiga memasukkan interaksi anatara job insecurity dengan religiusitas untuk mengetahui efek moderasi variabel. Hasilnya tidak ada peningkatan sumbangan efektif dan tidak terlihat efek moderasi dari interaksi antara job insecurity dan religiusitas $(\mathrm{p}=.738 ; \mathrm{p}>0,05)$ Sehingga dapat disimpulkan bahwa hipotesis penelitian yang menyebutkan menunjukkan religiusitas mempunyai peran yang signifikan terhadap stress kerja dengan sifat memperlemah $(\mathrm{p}=0,000, \mathrm{~B}=$ .263) dan mempunyai sumbangan efektif sebesar $14,7 \%$ dalam memprediksi stress kerja. Sehingga peneliti menyimpulkan bahwa religiusitas sebagai variabel independen murni dalam penelitian ini.

\section{Diskusi}

Penelitian ini bertujuan untuk menguji peran job insecurity terhadap stress kerja dimoderasi religiusitas. Hasil penelitian menunjukkan tidak terdapat peran moderasi religiusitas terhadap hubungan job insecurity dengan stress kerja $(\mathrm{p}=0,759$; $\mathrm{p}>0,05)$. Syarat kondisi sebuah variabel dikatakan sebagai moderator menurut Baron dan Kenny (1986) yaitu variabel moderator merupakan variabel yang bisa memberikan peran memperlemah atau memperkuat pengaruh variabel independen terhadap variabel dependen tidak terpenuhi karena tidak ada pengaruhnya terhadap sumbangan efektif dari tahapan pengujian; selanjutnya 
variabel moderator merupakan variabel yang dapat memoderasi berdasarkan hasil pengujian juga tidak terbukti karena peranan religiusitas sebagai moderator tidak signifikan.

Variabel moderator yang berhubungan dengan kriterion dan atau prediktor akan tetapi tidak berinteraksi dengan prediktor, maka variabel tersebut dapat dikatakan sebagai variabel intervening, eksogen, anteseden, atau prediktor (Sharma, Durrand, Gur-Arie, 1981). Religiusitas dalam penelitian ini tidak terbukti sebagai moderator terhadap peran job insecurity terhadap stress kerja, akan tetapi mempunyai peran signifikan secara langsung terhadap stress kerja. Berdasar pendapat Sharma, et al., (1981) maka religiusitas dapat berperan sebagai variabel prediktor terhadap stress kerja.

Hasil analisis menunjukkan adanya peranan signifikan job insecurity terhadap stress kerja. Hasil penelitian ini sejalan dengan penelitian oleh Greenhalgh dan Rosenblatt (1984) yang menunjukkan adanya hubungan antara job insecurity dengan stress. Ashford, et al., (1989) menyatakan job insecurity sebagai kondisi mental seorang karyawan di mana karyawan merasa pekerjaannya terancam dan karyawan tidak berdaya untuk melakukan sesuatu untuk mengatasi masalah. Ganster dan Rosen (2013) mengemukakan job control berfungsi menghambat laju stres kerja yang disebabkan oleh beban kerja, konflik, dan lain-lain. Berdasarkan hasil penelitian dan beberapa pendapat diatas kemudian dikaitkan ke dalam konteks dunia kerja karyawan perum perhutani yang bertugas di lapangan maka stress kerja dapat berkurang ketika karyawan ditingkatkan kewenangannya dalam merencanakan, mengontrol pekerjaannya maka diharap- kan dapat menurunkan tingkat stress kerja karyawan.

Stress kerja karyawan juga dapat dikurangi melalui peningkatan religiusitas. Penelitian yang dilakukan oleh Roostaee, Nikmanesh, Sharifi-Rad, Kiani, \& Shahnazi (2016) menyatakan adanya hubungan negatif antara religious coping dengan stress kerja. Semakin tinggi tingkat religiusitas seseorang dalam menghadapi masalah maka akan semakin rendah tingkat stres dalam menghadapi masalah kerja. Faktor terbesar yang berhubungan dengan stres kerja adalah aktivitas religious. Sehingga peningatan aktivitas religious karyawan diharapkan lebih mampu menurunkan stress kerja.

\section{Kesimpulan}

Berdasarkan hasil analisis data, diperoleh hasil bahwa variabel job insecurity berperan secara langsung terhadap stress kerja. Variabel religiusitas juga memiliki peran secara langsung terhadap stress kerja. Peranan job insecurity dan religiusitas secara bersama-sama akan meningkat sekitar $5,6 \%$ dalam memprediksi stres kerja. Namun variabel apabila dilakukan interaksi antara variabel job insecurity dan religiusitas maka peranannya tidak signifikan untuk memprediksi stres kerja.

\section{Saran}

Hasil penelitian ini dapat memberikan masukan bagi organisasi perum perhutani mengenai stress kerja karyawan, dan bagaimana mengelola stress kerja yang diinginkan. Perusahaan dapat menurunkan job insecurity karyawan dengan memberikan kepastian pekerjaan seperti deskripsi pekerjaan, bagaimana mekanisme penilaian hasil kerja. Pengelolaan religiusitas karyawan dapat dilakukan 
melalui program ritual keagamaan seperti pengajian rutin yang diagendakan. Dimungkinkan untuk mencoba penelitian sejenis dengan menggunakan subjek pada bagian supporting staff.

\section{Kepustakaan}

Ancok D \& Suroso F. N. (2011). Psikologi islami. Yogyakarta: Pustaka Pelajar

Ashford, S. J. et al., (1989). Content, cause, and consequences of job insecurity: A theory-based measure and substantive test. Academy of Management Journal, 32(4).

Astianto, A., (2014). Pengaruh stres kerja dan beban kerja terhadap kinerja karyawan PDAM Surabaya. Jurnal Ilmu Riset Manajemen, 3(7).

Baba, V. V., Jamal M., Tourigny, L. (1998). Work and mental health: A decade in Canadian research. Canadian Psychology, 39(1-2), 94-107

Baron, R. M., \& Kenny, D. A. (1986). The moderator - mediator variable distinction in social psychologycal research : Conceptual, strategic, and statistical consideration. Journal of Personality and Social Psychology. 51. $1173-1182$

Boswell, G, E. H. and Boswell-Ford, K. C. (2010). Testing a SEM model of two religious concepts and experiental spirituality. Journal of Religion and Health. 49(2), 200-211

Creswell, J. W., (2012). Educational research: planning, conducting, and evaluating quantitative and qualitative research, $4^{\text {th }}$ ed. New Jersey: Pearson Education, Inc.

Danna K., Griffin R. W., (1999). Health and wellbeing in the workplace: A review and synthesis of the literature. Journal of Management, 25, 357-384.
Erat, S. Kitapci, H. Comez, P. (2017). The effect of organizational loads on work stress, emotional commitment, and turnover intention. International Journal of Organizational Leadership, 6, 221-231

Fetzer Institute and national Institute on Aging Working Group. (1999). Multidimensional measurement of religiousness, spiritually for use in health research. Fetzer Institute in Collaboration with the National Institute on Aging. Kalamazo.

Ganster, D. C., \& Rosen, C. C., (2013). Work stress and employee health. Journal of Management, 39(5)

Greenhalgh, L., \& Rosenblatt, Z. (1984). Job insecurity: Toward conceptual clarity. Academy of Management Review, 9, 275-286

Handoko, H. (2013). Manajemen personalia dan sumberdaya manusia. Edisi Kedua, Cetakan kedua puluh. BPFE: Yogyakarta.

Idler, E. L., Musick, M. A., Ellison, C. G., George, L. K., Krause, N., Ory, M. G., (2003). Measuring multiple dimension of religion and spirituality for health research. Research on Aging, 25(4), 327-365.

Ismirani, M., (2011). Pengaruh religiusitas dan adversity quotien terhadap stres kerja pada agen asuransi jiwa bersama Bumiputera 1912. Skripsi. Jakarta: UIN Syarif Hidayatullah.

Jamal M. (1984). Job stress and job performance controversy: An empirical assessment. Organizational Behavior and Human Performance, 33, 1-21

Jamal, M. (2011). Job stress, job performance and organizational commitment in a multinational company: An empirical study in two 
country. International Journal of Business and Social Science, 2(20).

Koenig, H. G., Stephen M. F, Linda K. George, \& G. Blazer, \& Keith G. Meador. (1993). Religion and anxiety disorder: An examination and comparison of associations in young, middle-aged, and elderly adults. Journal of Anxiety Disorder, 7, 321-342

Koenig, Harold G. Linda K. George, Dan G. Blazer, Keith G. Meador, and Peter B. Dyk. (1994). Religious affiliation and psychiatric disorders among protestan baby boomers." Hospital \& Community Psychiatry, 45, 586-596

Lazarus, R. S, and Folkman, S (1984). Stress, appraisal, and coping. New York: Springer Publishing Company.

Mc Elwee, P. (2008). You say illegal, i say legal: The relationship between 'illegal' logging and land tenure, poverty, and forest use rights in Vietnam. Journal of Sustainable Forestry, 19.

Park. Soo Kyung., Rhee. Min-Kyoung., \& Barak. Michalle Mor., (2016), Job stress and mental health among nonregular workers in Korea : What dimensions of job stress are associated with mental health. Journal Archives of Environmental $\mathcal{E}$ Occupational Health, 71(2).

Peluso, Nancy Lee (2011). Emergent forest and private land regimes in Java. The Journal of Peasant Studies, 38.

Tsutsumi, A., Kayaba, K., Theorel, T. \& Siegrist, J. (2001). Association between job stress and depression among Japanese employees threatened by job loss in a comparison between two complementary job-stress models., Scandinavian Journal of Work Environment Health, 27(2), 146-153.

Robbins, Stephen. P. \& Judge, Timothy. A. (2015). Perilaku organisasi. Jakarta: Salemba Empat.

Roostaee, F. Nikmanesh, Z. Sharifi-Rad, J. Kiani, M. Shahnazi, A. (2016). Relation of religious coping with occupational stress and quality of work life for midwives working in maternity hospitals in Zahedan, Iran. International Journal of Research in Medical Sciences, 4(12).

Safaria, T. (2011). Peran religious coping sebagai moderator dari Job Insecurity terhadap stres kerja pada staf akademik. Humanitas, 8(2).

Sauter S., Hurrel J., Murphy L., Levi L., (1997). Psychosocial and organizational factors. Encyclopedia of occupational health and safety. 1, Geneva, Switzerland. International Labour Office.

Sharma, S., Durand, R.M., \& Gur-Arie, O. (1981). Identification and analysis of moderator variables. Journal of Marketing Research, 18, 291-300

Sur. Sujit,. \& Ng. Eddy S., (2014). Extending theory on job stress. Human Resources Development Review, 13(1).

Urbayatun, S \& Widhiarso, W. (2012). Variabel mediator dan moderator dalam penelitian psikologi kesehatan masyarakat. Jurnal Psikologi. 39(2), 180-188 